\title{
Kajian Perubahan Ragam Genetik Tanaman Jagung (Zea mays L.) Akibat Seleksi
}

\section{Study of Genetic Variation Change on Maize (Zea mays L.) as a Result of Selection}

\author{
I Wayan Sudika*, I Wayan Sutresna, Dwi Ratna Anugrahwati \\ Program Studi Agroekoteknologi Jurusan Budidaya Pertanian, \\ Fakultas Pertanian, Universitas Mataram \\ Jl. Majapahit 62 Mataram 83125, Telp.(0370) 646506 INDONESIA \\ *corresponding author, email: sudikawayanms@gmail.com
}

Manuscript received: 03-07-2019. Accepted: 25-12-2019

\begin{abstract}
ABSTRAK
Penelitian ini bertujuan untuk mengetahui perubahan ragam genetik total setelah dilakukan delapan siklus seleksi massa dengan teknik indeks seleksi untuk daya hasil, berangkasan segar, dan bobot tongkol kering panen tanaman jagung dan untuk mengetahui rata-rata ketiga karakter tersebut dibandingkan dengan populasi awal. Percobaan dilaksanakan di kecamatan Pringgabaya Kabupaten Lombok Timur. Rancangan percobaan yang digunakan adalah Rancangan Acak Kelompok (RAK) 11 perlakuan, yaitu delapan populasi hasil seleksi, populasi awal dan dua varietas hibrida. Setiap perlakuan diulang 3 kali, sehingga diperoleh 33 unit percobaan. Data hasil percobaan dianalisa dengan analisis sidik ragam pada taraf nyata 5 persen. Ragam fenotip diperoleh dari ragam sampel; sedangkan ragam lingkungan merupakan rata-rata ragam fenotip dua hibrida. Ragam genetik diperoleh dari ragam fenotip masing-masing populasi dikurangi ragam lingkungan. Guna mengetahui ragam genetik populasi siklus kedelapan sama atau berbeda dengan populasi awal, maka dilakukan uji- $\mathrm{F}_{0.05}$. Rata-rata antar populasi awal dengan populasi siklus kedelapan, diuji dengan uji $\mathrm{BNT}_{0.05}$. Hasil penelitian menunjukkan, bahwa ragam genetik total populasi hasil seleksi siklus kedelapan untuk daya hasil, bobot tongkol kering panen dan berangkasan segar lebih kecil dibanding ragam genetik populasi awal. Rata-rata daya hasil, bobot tongkol kering panen dan berangkasan segar populasi hasil seleksi siklus delapan lebih tinggi dibanding populasi awal.
\end{abstract}

Kata kunci: brangkasan; hibrida; hasil; indeks; massa

ABSTRACT
This study aimed to determine the change in total genetic diversity after eight cycles of mass selection
using a technique of selection index for yield, fresh dry matter, and weight of dry harvested cob, and to
find out the average of these three characters compared to the initial population. This experiment was
carried out at Pringgabaya District, East Lombok Regency using Randomized Block Design (RBD)
with 11 treatments, namely eight selected populations, initial populations and two hybrid varieties. Each
treatment was replicated 3 times, resulted in 33 experimental units. Data obtained were analyzed using


analysis of variance at 0.05 levels. Variance of phenotype is obtained from the variety of samples; while the environmental variance is defined as the average variance of the two hybrid phenotypes. Genetic diversity is obtained from the variety of phenotypes of each population minus the environmental diversity. F-test of 0.05 was performed to find out whether the genetic diversity of the eighth cycle population is the same or different to that of the genetic diversity of the initial population. The average between the initial population and the eighth cycle population was tested using the HSD-test at 0.05 levels. The results showed that the total genetic variation in the population from the eighth cycle selection for yield, harvested dry weight of cobs, and fresh dry matter of maize were smaller than the genetic diversity of the initial population. The average yield, harvested dry cob weight and fresh dry matter weight of population of the eighth cycle selection are higher than the initial population.

Keyword: biomass; hybrid; yield; index; mass

\section{PENDAHULUAN}

Karakter daya hasil dan brangkasan segar tanaman jagung telah diperbaiki menggunakan metode seleksi massa dengan seleksi indeks selama delapan siklus di lahan kering. Seleksi massa adalah seleksi yang digunakan untuk mengembangkan varietas dengan berbagai genotipe; yang populasi dasarnya mempunyai keragaman genetik tinggi Seleksi massa merupakan salah satu seleksi berulang. Menurut Syukur at all (2012), bahwa seleksi massa akan berhasil apabila ditujukan untuk memperbaiki karakter yang memiliki heritabilitas tinggi. Andriani et al. (2015) menambahkan, bahwa perbaikan genetik suatu populasi akan berhasil apabila dalam populasi tersebut terdapat variabilitas genetik tinggi. Besar kecilnya peningkatan rerata populasi setiap siklus, digambarkan dari rata-rata kemajuan seleksi per siklus. Prediksi kemajuan seleksi yang diperoleh, memerlukan pengetahuan tentang nilai keragaman genetik, ragam fenotipe, intensitas seleksi dan koefisien seleks.

Seleksi terhadap dua sifat atau lebih dapat dilakukan secara tandem, independent culling level dan seleksi indeks. Seleksi indeks memberikan informasi dari semua sifat ke dalam suatu indeks, dengan demikian memungkinkan memberi skor total pada setiap individu. Metode ini dilakukan terhadap beberapa sifat secara simultan dan pertimbangan-pertimbangan lain yang dipakai pemulia tanaman hanya berdasar bobot nisbi yang diberikan terhadap masing-masing sifat. Menurut Asghar dan Mehdi (2010), bahwa seleksi indeks dasar untuk beberapa sifat akan lebih efektif dibanding seleksi indeks Smith-Hazel. Sudika et al. (2018) telah melakukan seleksi indeks dasar dan mengujinya hingga siklus ketujuh. Rata-rata kemajuan seleksi per siklus daya hasil (berat biji kering pipil per plot) sebesar 72.80 gplot $^{-1}$ bersifat linear yang nyata dan untuk bobot brangkasan segar per tanaman sebesar 11.50 gplot $^{-}$ ${ }^{1}$ juga bersifat linear yang nyata. Seleksi menyebabkan perubahan rerata dan ragam populasi. Ragam populasi terdiri atas ragam genetik, ragam lingkungan dan ragam interaksi genetik dengan lingkungan (Andriani et al., 2015)

Peningkatan rata-rata populasi akibat seleksi massa diikuti pula oleh penurunan ragam genetik karena semakin seragamnya tanaman terpilih. Disisi lain, dalam setiap siklus seleksi, selalu dilakukan rekombinasi genetik untuk mempertahankan keragaman genetik, sehingga seleksi dapat dilakukan pada siklus berikutnya. Selain itu, besarnya intensitas seleksi sangat menentukan besarnya peningkatan rerata dan penurunan ragam genetik sifat yang diseleksi pada seleksi berulang, seperti seleksi massa (Peter dan Lamkey, 2000). Dalam penelitian ini 
dilakukan seleksi massa dengan menggunakan indeks seleksi hingga siklus ke delapan guna peningkatan daya hasil dan brangkasan segar, namun belum diketahui perubahan ragam genetik dan peningkatan sifat tersebut. Penelitian ini ditujukan untuk mengetahui perubahan ragam genetik total setelah dilakukan delapan siklus seleksi massa dengan menggunakan indeks seleksi untuk daya hasil, berangkasan segar, dan bobot tongkol kering panen tanaman jagung dan untuk mengetahui rata-rata populasi hasil seleksi ketiga karakter tersebut dibandingkan dengan populasi awal.

\section{BAHAN DAN METODE}

Percobaan telah dilaksanakan di Desa Pringgabaya, kabupaten Lombok Timur pada tanah bertekstur geluh. Kegiatan dimulai bulan April sampai dengan bulan Agustus 2019. Benih jagung yang digunakan berupa Hibrida Bisi 2 dan NK212 serta populasi awal dan populasi hasil seleksi (1-8).

\section{Rancangan percobaan}

Percobaan dirancang dengan Rancangan Acak Kelompok dengan 11 perlakuan (populasi) dan diulang sebanyak 3 kali. Adapun perlakuan meliputi: P0 = Populasi awal (hasil rakitan kultivar lokal); P1 hingga P8 berturut-turut merupakan populasi hasil seleksi massa dengan indeks seleksi siklus pertama, kedua, ketiga, keempat, kelima, keenam, ketujuh dan kedelapan, varietas hibrida NK212 dan hibrida Bisi-2.

\section{Pelaksanaan}

Sebelum ditanam, benih diperlakukan dengan Saromyl 35 SD dengan dosis $5 \mathrm{gkg}^{-1}$ benih untuk mencegah penyakit bulai (Seclerospora maydis). Pengolahan tanah dilakukan dengan membajak dan menggaru masing-masing sebanyak satu kali, kemudian tanah diratakan dengan cangkul. Selanjutnya petak percobaan, dibagi menjadi 3 blok dengan jarak antar blok $1 \mathrm{~m}$. Antar blok dipisahkan dengan pematang untuk memudahkan pengairan.

Penanaman dilakukan dengan cara menugal tanah kurang lebih sedalam $5 \mathrm{~cm}$ dan setiap lubang diisi dua biji benih. Jarak tanam yang digunakan adalah 20 x $60 \mathrm{~cm}$. Pada setiap lubang tanam, diberikan Furadan 3G untuk mencegah serangan hama, kemudian lubang ditutup dengan tanah. Setiap perlakuan, ditanam 5 baris dan masing-masing baris berisi 20 tanaman, sehingga jumlah tanaman setiap perlakuan maksimal sebanyak 100 tanaman.

Pemupukan dilakukan sebanyak dua kali, secara bertahap dengan menggunakan pupuk NPK Phonska (15-15-15) dan pupuk Urea. Dosis untuk pupuk Phonska sebanyak 300 kgha $^{-1}$ dan pupuk urea sebanyak $200 \mathrm{kgha}^{-1}$ yang diberikan dua kali; masing-masing setelah dosis. Pemupukan pertama, dilakukan pada saat tanam dan pemupukan kedua dilakukan setelah tanaman berumur 28 hari. Pemupukan pertama, dilakukan dengan menugal sebelah kiri atau kanan lubang tanam dengan jarak sekitar $10 \mathrm{~cm}$ dari lubang tanam; sedangkan pemupukan kedua, dilakukan dengan menugal di antara tanaman dalam barisan.

Penyulaman dan penjarangan dilakukan untuk mempertahankan jumlah tanaman satu per lubang. Penyulaman dilakukan pada umur tanaman 10 hari setelah tanam. Penyulaman dilakukan terhadap tanaman yang mati atau tidak tumbuh, dengan menggunakan tanaman 
cadangan. Penjarangan dilakukan pada umur 14 hari setelah tanam, dengan mencabut salah satu tanaman yang pertumbuhannya lebih jelek pada setiap lubang.

Penyiangan dan pembumbunan dilakukan untuk mengendalikan gulma sekaligus memperkokoh tanaman. Penyiangan dilakukan dengan menyemprotkan herbisida Calaris 550 SC pada umur 17 hari setelah tanam. Pembumbunan dilakukan pada umur 25 hari setelah tanam dengan cara mencangkul tanah di antara barisan tanaman. Tanah tersebut ditimbunkan ke kiri dan ke kanan, sehingga nampak seperti guludan pada setiap baris.

Pengairan dilakukan sehari sebelum tanam, kemudian dengan selang waktu 10 hari hingga umur 70 hari setelah tanam. Pengairan dilakukan dengan cara leb, yakni petakan digenangi hingga permukaan air rata dengan permukaan tanah; selanjutnya air dialirkan ke petakan yang lain. Pengendalian hama penggerek bunga jantan, dilakukan dengan menyemprotkan larutan Alika 247 ZC dicampur dengan Prevaton 50 SC pada umur 38 hari. Dengan dosis 400 Lha $^{-1}$ Panen dilakukan setelah $85 \%$ tanaman dalam setiap plot memenuhi kriteria panen. Kriteria panen yang digunakan yaitu rambut tongkol telah kering, biji keras, kelobot telah berwarna kuning dan kering, serta biji mengkilap dan apabila dipijit tidak berbekas.

\section{Variabel dan analisis data}

Variabel yang diamati meliputi tinggi tanaman, jumlah daun total per tanaman, jumlah daun segar saat panen, diameter tongkol, panjang tongkol, bobot tongkol kering panen per tanaman, bobot brangkasan segar per tanaman dan bobot biji kering pipil per tanaman.

Ragam genetik total diperoleh dengan menggunakan analisis statistik sederhana dengan langkah-langkah sebagai berikut:

1) Menghitung ragam fenotipe setiap perlakuan dengan rumus:

$$
\sigma^{2} \mathrm{Pj}=\frac{(\mathrm{xi}-\overline{\mathrm{x}})^{2}}{\mathrm{n}-1}
$$

2) Pendugaan ragam lingkungan diperoleh dengan cara sebagai berikut:

$$
\sigma^{2} \mathrm{E}=\frac{\left(\sigma^{2} \mathrm{PBisi} 2+\sigma^{2} \mathrm{PNK} 212\right)}{2}
$$

3) Menghitung ragam genetik total setiap perlakuan dengan rumus:

$\sigma^{2} \mathrm{Gj}=\sigma^{2} \mathrm{Pj}-\underline{\sigma^{2} \mathrm{E}}$ dengan $\mathrm{j}$ bergerak dari 0 sampai 8 .

4) Perbedaan ragam genetik total populasi siklus 8 diuji dengan uji-F pada taraf nyata 5 persen sebagai berikut:

$\mathrm{F}$ hit $=\frac{\sigma^{2} \mathrm{G} P 0}{\sigma^{2} \mathrm{G} \text { P8 }} ;$ kemudian dibandingkan dengan $\mathrm{F}_{0.05}$ 
Guna menentukan perbedaan daya hasil dan sifat lain antar perlakuan, maka dilakukan analisis ragam dan selanjutnya dilakukan uji lanjut dengan Uji beda Nyata Terkecil (BNT) pada taraf nyata $5 \%$.

\section{HASIL DAN PEMBAHASAN}

Hasil analisis data tentang ragam fenotip sifat yang diamati untuk setiap populasi disajikan pada Tabel 1 dan ragam genetik totalnya, disajikan pada Tabel 2 dan Tabel 3.

Tabel 1. Ragam fenotip setiap populasi untuk setiap sifat yang diamati

\begin{tabular}{ccccccccc}
\hline \multirow{2}{*}{ Populasi } & \multicolumn{7}{c}{ Ragam fenotip } \\
\cline { 2 - 8 } & 1 & 2 & 3 & 4 & 5 & 6 & 7 & 8 \\
\hline P0 & 1338.69 & 2.30 & 3.49 & 0.22 & 7.71 & 1986.72 & 7132.79 & 589.33 \\
P1IS & 1221.65 & 2.08 & 2.98 & 0.23 & 7.18 & 1704.17 & 7515.72 & 573.32 \\
P2IS & 1210.34 & 2.27 & 2.96 & 0.20 & 6.87 & 1714.58 & 6214.79 & 555.65 \\
P3IS & 1207.38 & 1.98 & 2.85 & 0.19 & 7.42 & 1750.96 & 5523.66 & 575.28 \\
P4IS & 1293.42 & 1.98 & 2.44 & 0.19 & 7.45 & 1742.16 & 5806.43 & 563.16 \\
P5IS & 1216.46 & 2.14 & 2.42 & 0.20 & 7.08 & 1685.78 & 5257.51 & 518.55 \\
P6IS & 1128.09 & 2.01 & 2.71 & 0.16 & 5.62 & 1523.28 & 4678.26 & 519.99 \\
P7IS & 960.92 & 2.01 & 2.46 & 0.10 & 4.83 & 1294.54 & 4369.38 & 549.34 \\
P8IS & 993.98 & 2.04 & 2.39 & 0.09 & 4.80 & 828.76 & 4155.62 & 448.56 \\
Bisi-2 & 527.77 & 1.91 & 1.58 & 0.05 & 2.61 & 585.90 & 3950.48 & 255.06 \\
NK212 & 465.86 & 1.31 & 1.65 & 0.04 & 1.77 & 662.70 & 4345.97 & 261.18 \\
\hline Rata-rata & 496.81 & 1.61 & 1.61 & 0.04 & 2.19 & 624.30 & 4148.23 & 258.12 \\
2 Hibrida & & & & & & \\
\hline
\end{tabular}

Keterangan:1.Tinggi tanaman (cm), 2. jumlah daun total (helai), 3. jumlah daun segar (helai), 4. diameter tongkol $(\mathrm{cm})$, 5. panjang tongkol $(\mathrm{cm}), 6$. bobot tongkol kering panen per tanaman $(\mathrm{g}), 7$. bobot brangkasan segar per tanaman $(\mathrm{g})$ dan 8. bobot biji kering pipil per tanaman $(\mathrm{g})$

Keragaman sifat dalam suatu populasi disebabkan oleh keragaman genetik dan keragaman lingkungan, yang besarnya diukur dan dinyatakan sebagai varian. Keragaman genetik merupakan perbedaan yang ditimbulkan oleh perbedaan genotipe dalam populasi. Keragaman fenotip yang terjadi merupakan akibat adanya keragaman genetik dan keragaman lingkungan (Andriani et al., 2015). Ragam fenotip pada Tabel 1, ini digunakan untuk menghitung besarnya ragam genetik total setiap sifat yang diamati pada setiap siklus seleksi. Nilai rata-rata ragam fenotip hibrida Bisi-2 dan NK212 merupakan penduga untuk ragam lingkungan. Oleh karena itu, ragam genetik total diperoleh dari pengurangan ragam fenotip setiap sifat dengan rata-rata ragam fenotip dua hibrida. Seluruh sifat yang diamati, memiliki ragam fenotip yang lebih besar dibanding rata-rata ragam fenotip dua hibrida. Hal ini ini dapat terjadi karena hibrida merupakan F1; yang tersusun dari genotip seragam; sedangkan populasi hasil seleksi merupakan komposit; yang terdiri atas berbagai genotip (Mejaya, et al., 2010). Hal tersebut menyebabkan penampilan tanaman di lapangan akan lebih seragam pada populasi hibrida dibanding populasi setiap siklus seleksi (Kutka, 2011). 
Tabel 2. Ragam genetik total setiap populasi untuk tinggi tanaman, jumlah daun total, jumlah daun segar saat panen dan bobot brangkasan segar per tanaman

\begin{tabular}{|c|c|c|c|c|c|c|c|c|}
\hline \multirow{3}{*}{ Populasi } & \multicolumn{8}{|c|}{ Sifat yang diamati } \\
\hline & \multicolumn{2}{|c|}{1} & \multicolumn{2}{|c|}{2} & \multicolumn{2}{|c|}{3} & \multicolumn{2}{|c|}{4} \\
\hline & $\sigma^{2} \mathrm{G}$ & $\Delta \sigma^{2} \mathrm{G}$ & $\sigma^{2} \mathrm{G}$ & $\Delta \sigma^{2} \mathrm{G}$ & $\sigma^{2} \mathrm{G}$ & $\Delta \sigma^{2} \mathrm{G}$ & $\sigma^{2} \mathrm{G}$ & $\Delta \sigma^{2} \mathrm{G}$ \\
\hline P0 & $841.88 \mathrm{a}$ & & $0.69 \mathrm{a}$ & & $1.88 \mathrm{a}$ & & $2984.56 \mathrm{a}$ & \\
\hline P1IS & $724.84 \mathrm{a}$ & 117.04 & $0.47 \mathrm{a}$ & 0.22 & $1.37 \mathrm{a}$ & 0.51 & $3367.49 \mathrm{a}$ & 382.93 \\
\hline P2IS & $713.53 \mathrm{a}$ & 128.35 & $0.66 \mathrm{a}$ & 0.03 & $1.35 \mathrm{a}$ & 0.53 & $2066.56 \mathrm{a}$ & 918.00 \\
\hline P3IS & $710.57 \mathrm{a}$ & 131.31 & $0.37 \mathrm{~b}$ & 0.32 & $1.24 \mathrm{a}$ & 0.64 & $1375.43 \mathrm{~b}$ & 1609.13 \\
\hline P4IS & $796.61 \mathrm{a}$ & 45.27 & $0.37 \mathrm{~b}$ & 0.32 & $0.83 \mathrm{~b}$ & 1.05 & $1658.20 \mathrm{~b}$ & 326.36 \\
\hline P5IS & $719.65 \mathrm{a}$ & 122.23 & $0.53 \mathrm{~b}$ & 0.16 & $0.81 \mathrm{~b}$ & 1.07 & $1109.28 \mathrm{~b}$ & 1875.28 \\
\hline P6IS & $631.28 \mathrm{a}$ & 210.60 & $0.40 \mathrm{~b}$ & 0.29 & $1.10 \mathrm{~b}$ & 0.79 & $530.03 \mathrm{~b}$ & 2454.53 \\
\hline P7IS & $464.11 \mathrm{~b}$ & 377.77 & $0.40 \mathrm{~b}$ & 0.29 & $0.85 \mathrm{~b}$ & 1.03 & $221.15 \mathrm{~b}$ & 2763.41 \\
\hline P8IS & $497.17 \mathrm{~b}$ & 344.71 & $0.43 \mathrm{~b}$ & 0.26 & $0.78 \mathrm{~b}$ & 1.10 & $7.39 \mathrm{~b}$ & 2977.17 \\
\hline
\end{tabular}

Keterangan:Angka-angka pada kolom yang sama diikuti oleh huruf yang sama menunjukkan tidak berbeda nyata dengan P0 pada uji- $\mathrm{F}_{0.05} . \sigma^{2} \mathrm{G}$ : ragam genetik. $\Delta \sigma^{2} \mathrm{G}$. perubahan ragam genetik. 1 . tinggi tanaman $(\mathrm{cm}), 2$. jumlah daun total per tanaman (helai), 3. jumlah daun segar per tanaman saat panen (helai) dan 4. bobot brangkasan segar per tanaman

Tabel 3. Ragam genetik total komponen hasil dan hasil tanaman jagung

\begin{tabular}{ccccccccc}
\hline & \multicolumn{7}{c}{ Sifat yang diamati } \\
\cline { 2 - 9 } Populasi & \multicolumn{7}{c}{1} & \multicolumn{7}{c}{3} & \multicolumn{2}{c}{4} \\
\cline { 2 - 9 } & $\sigma^{2} \mathrm{G}$ & $\Delta \sigma^{2} \mathrm{G}$ & $\sigma^{2} \mathrm{G}$ & $\Delta \sigma^{2} \mathrm{G}$ & $\sigma^{2} \mathrm{G}$ & $\Delta \sigma^{2} \mathrm{G}$ & $\sigma^{2} \mathrm{G}$ & $\Delta \sigma^{2} \mathrm{G}$ \\
\hline P0 & $0.18 \mathrm{a}$ & & $5.52 \mathrm{a}$ & & $1362.42 \mathrm{a}$ & & $331.21 \mathrm{a}$ & \\
P1IS & $0.19 \mathrm{a}$ & 0.01 & $4.99 \mathrm{a}$ & 0.53 & $1079.87 \mathrm{a}$ & 282.55 & $315.20 \mathrm{a}$ & 16.01 \\
P2IS & $0.16 \mathrm{a}$ & 0.02 & $4.68 \mathrm{a}$ & 0.84 & $1090.28 \mathrm{a}$ & 272.14 & $297.53 \mathrm{a}$ & 33.68 \\
P3IS & $0.15 \mathrm{a}$ & 0.03 & $5.23 \mathrm{a}$ & 0.29 & $1126.66 \mathrm{a}$ & 235.76 & $317.16 \mathrm{a}$ & 14.04 \\
P4IS & $0.15 \mathrm{a}$ & 0.03 & $5.26 \mathrm{a}$ & 0.26 & $1117.86 \mathrm{a}$ & 244.55 & $305.04 \mathrm{a}$ & 26.17 \\
P5IS & $0.16 \mathrm{a}$ & 0.02 & $4.89 \mathrm{a}$ & 0.63 & $1061.48 \mathrm{a}$ & 300.94 & $260.43 \mathrm{a}$ & 70.77 \\
P6IS & $0.12 \mathrm{a}$ & 0.06 & $3.43 \mathrm{~b}$ & 2.09 & $898.98 \mathrm{a}$ & 463.44 & $261.87 \mathrm{a}$ & 69.34 \\
P7IS & $0.06 \mathrm{~b}$ & 0.12 & $2.64 \mathrm{~b}$ & 2.88 & $670.24 \mathrm{~b}$ & 692.18 & $291.22 \mathrm{a}$ & 39.98 \\
P8IS & $0.05 \mathrm{~b}$ & 0.13 & $2.61 \mathrm{~b}$ & 2.91 & $204.46 \mathrm{~b}$ & 1157.95 & $190.44 \mathrm{~b}$ & 140.77 \\
\hline
\end{tabular}

Keterangan:Angka-angka pada kolom yang sama diikuti oleh huruf yang sama menunjukkan tidak berbeda nyata terhadap P0 pada uji- $\mathrm{F}_{0.05} . \sigma^{2} \mathrm{G}$ : ragam genetik. $\Delta \sigma^{2} \mathrm{G}$. perubahan ragam genetik. 1 . diameter tongkol $(\mathrm{cm}), 2$. panjang tongkol $(\mathrm{cm}), 3$. bobot tongkol kering panen per tanaman $(\mathrm{g})$ dan 4. Bobot biji kering pipil per tanaman $(\mathrm{g})$

Pada Tabel 2 dan Tabel 3 terlihat, bahwa ragam genetik total populasi siklus ketujuh dan kedelapan lebih kecil dibanding ragam genetik total populasi awal untuk seluruh sifat yang diamati, kecuali bobot biji kering pipil per tanaman, hanya populasi siklus ke delapan yang lebih kecil. Ragam genetik total mulai populasi siklus ketiga jumlah daun total per tanaman dan bobot brangkasan segar per tanaman lebih kecil dibanding populasi awal. Hal ini 
menunjukkan, bahwa rekombinasi genetik tidak mampu mempertahankan keragaman sejak siklus ketiga. Selain itu mungkin pula disebabkan oleh jumlah tanaman terpilih lima persen yang kurang besar. Jumlah tanaman terpilih menentukan nilai intensitas seleksi. Hal ini sesuai dengan pendapat Peter dan Lamkey (2000), bahwa intensitas seleksi turut pula berperan dalam mempertahankan keragaman genetik pada populasi berulang.

Sifat yang diseleksi adalah bobot tongkol kering panen dan bobot berangkasan segar, sedangkan sifat yang diperbaiki adalah bobot biji kering pipil dan bobot berangkasan segar. Berdasarkan Tabel 2, ragam genetik sifat yang diseleksi pada bobot tongkol kering panen berubah secara nyata pada populasi P7IS dan P8IS; sedangkan pada bobot berangkasan segar menunjukkan ragam genetik yang berubah secara nyata pada populasi P3IS, P5IS, P6IS, P7IS, dan P8IS. Ragam genetik pada daya hasil atau bobot biji kering pipil berubah secara nyata pada populasi P8IS. Perubahan ragam genotip total secara nyata menunjukkan bahwa nilai ragam populasi suatu siklus tidak sama dengan populasi awal (P0). Ragam genetik pada P8IS lebih kecil dibanding dengan P0. Hal ini disebabkan oleh proses seleksi yang telah dilakukan selama 8 siklus. Semakin banyak siklus seleksi, maka akan menyebabkan terjadinya perubahan rerata yang umumnya semakin meningkat. Peningkatan rerata akan diikuti oleh pengurangan ragam genetik pada populasi yang diseleksi. Berkurangnya ragam genetik total disebabkan oleh dalam melakukan seleksi, dipilih tanaman-tanaman yang bobot tongkol dan bobot brangkasan segar lebih tinggi sebanyak 5\%, sehingga didalam populasi hasil seleksi akan menjadi lebih seragam. Penurunan tersebut terjadi akibat berkurangnya frekuensi gen dan frekuensi genotip yang berkenan.

Persentase penurunan ragam genetik total sifat yang diseleksi dan sifat yang diperbaiki berbeda seperti terlihat pada Gambar 1. Persentase penurunan paling tinggi, yakni $99.75 \%$ terjadi pada bobot brangkasan segar per tanaman, kemudian diikuti oleh bobot tongkol kering panen per tanaman sebesar $84.99 \%$ dan penurunan paling kecil terjadi pada bobot biji kering pipil per tanmaan (daya hasil), yakni sebesar $42.51 \%$. Hal ini dapat terjadi karena bobot brangkasan segar per tanaman merupakan sifat yang diseleksi sekaligus sifat yang diperbaiki. Daya hasil merupakan sifat yang diperbaiki melalui bobot tongkol kering panen per tanaman, sehingga penurunan ragam genetiknya paling kecil.

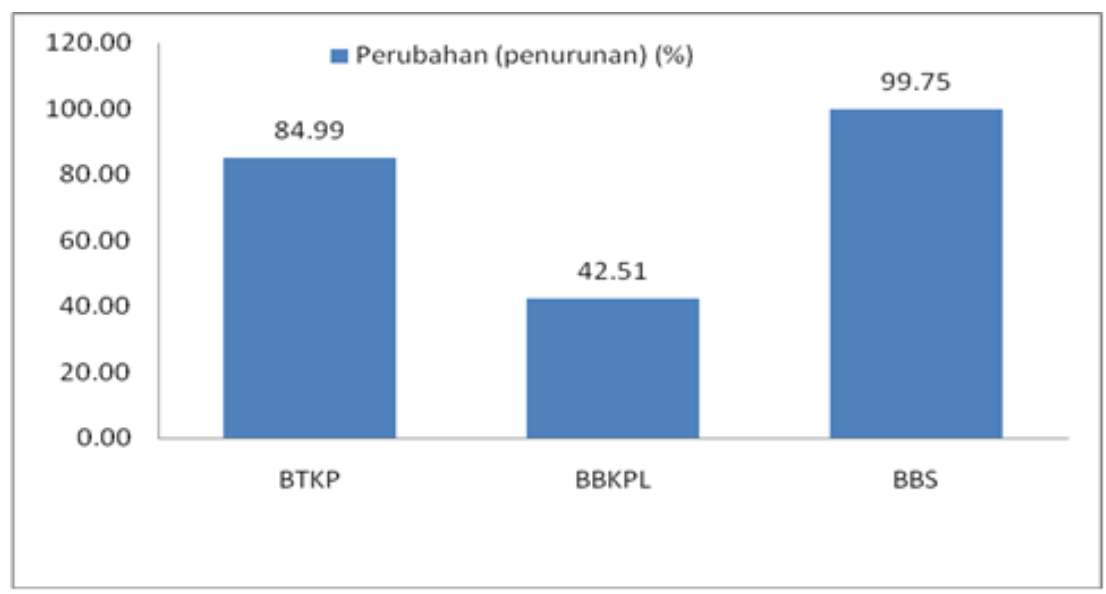

Gambar 1. Persentase penurunan ragam genetik total tiga sifat tanaman jagung. 
Setiap siklus seleksi dilakukan rekombinasi genetik guna mempertahankan ragam genetik. Penurunan ragam genetik secara nyata mengindikasikan bahwa rekombinasi genetik yang dilakukan tidak mampu mempertahankan keragaman genetik atau rekombinasi genetik tidak efektif. Sifat bobot tongkol kering panen menunjukkan bahwa pada populasi siklus ke-7 dan ke- 8 terjadi penurunan nilai ragam genetik yang besar; berarti rekombinasi genetik mampu mempertahankan keragaman genetik populasi hingga siklus keenam; namun untuk brangkasan segar per tanaman efektif hingga siklus kedua. Penurunan ragam genetik secara nyata terjadi pada siklus ke delapan; berarti rekombinasi genetik efektif hingga siklus ke tujuh. Peter dan Lamkey (2000) memperoleh, bahwa ragam genetik daya hasil jagung tidak berubah setelah dilakukan lima siklus seleksi.

Seleksi massa dengan indeks seleksi menyebabkan perubahan rerata populasi pada setiap siklus seleksi, seperti terlihat pada Tabel 4 dan Tabel 5. Pada Tabel 4 terlihat, bahwa jumlah daun segar saat panen dan bobot brangkasan segar lebih besar dibanding populasi awal mulai siklus pertama; namun tinggi tanaman mulai siklus kedua. Jumlah daun total per tanaman tidak mengalami peningkatan akibat delapan siklus seleksi.

Tabel 4. Rata-rata tinggi tanaman. jumlah daun total. jumlah daun segar saat panen dan bobot brangkasan segar per tanaman setiap perlakuan

\begin{tabular}{ccccc}
\hline \multirow{2}{*}{ Populasi } & \multicolumn{4}{c}{ Sifat-sifat yang diamati } \\
\cline { 2 - 5 } & 1 & 2 & 3 & 4 \\
\hline P0 & $179.52 \mathrm{a}$ & 10.85 & $6.00 \mathrm{a}$ & $219.58 \mathrm{a}$ \\
P1IS & $182.54 \mathrm{a}$ & 10.95 & $6.85 \mathrm{~b}$ & $284.86 \mathrm{~b}$ \\
P2IS & $198.74 \mathrm{~b}$ & 11.00 & $6.77 \mathrm{~b}$ & $275.22 \mathrm{~b}$ \\
P3IS & $194.11 \mathrm{~b}$ & 10.92 & $7.00 \mathrm{~b}$ & $281.94 \mathrm{~b}$ \\
P4IS & $194.01 \mathrm{~b}$ & 10.42 & $7.00 \mathrm{~b}$ & $279.45 \mathrm{~b}$ \\
P5IS & $193.36 \mathrm{~b}$ & 11.12 & $7.13 \mathrm{~b}$ & $330.88 \mathrm{~b}$ \\
P6IS & $205.94 \mathrm{~b}$ & 10.92 & $6.80 \mathrm{~b}$ & $340.61 \mathrm{~b}$ \\
P7IS & $206.47 \mathrm{~b}$ & 11.40 & $7.25 \mathrm{~b}$ & $346.62 \mathrm{~b}$ \\
P8IS & $209.65 \mathrm{~b}$ & 11.40 & $7.32 \mathrm{~b}$ & $351.47 \mathrm{~b}$ \\
\hline BNT $_{0.05}$ & 10.89 & & 0.54 & 43.65 \\
\hline
\end{tabular}

Keterangan:Angka-angka pada kolom yang sama diikuti oleh huruf yang sama menunjukkan tidak berbeda nyata dengan $\mathrm{P} 0$ pada uji $\mathrm{BNT}_{0.05}$. 1. tinggi tanaman $(\mathrm{cm})$, 2. jumlah daun total per tanaman (helai), 3. jumlah daun segar per tanaman saat panen (helai) dan 4 . bobot brangkasan segar per tanaman (g).

Pada Tabel 5 terlihat pula, bahwa diameter tongkol lebih besar sejak siklus siklus pertama; panjang tongkol dan bobot tongkol kering panen per tanaman sejak siklus kelima dan untuk daya hasil (bobot biji kering pipil per tanaman) lebih tinggi dibanding populasi awal sejak siklus keenam. Nilai koefisien korelasi fenotipik antara daya hasil dengan sifat lain disajikan pada Tabel 6 .

Pada Tabel 6 terlihat, seluruh sifat yang diamati memiliki nilai koefisien korelasi positif nyata dengan daya hasil; namun besarnya berlainan. Jumlah daun total per tanaman dan jumlah daun segar saat panen per tanaman memiliki nilai koefisien korelasi $<0.50$ dan sifat lain $>$ 0.50 . 
Tabel 5. Rata-rata sifat komponen hasil dan hasil tanaman jagung setiap perlakuan

\begin{tabular}{ccccc}
\hline \multirow{2}{*}{ Populasi } & \multicolumn{4}{c}{ Sifat sifat yang diamati } \\
\cline { 2 - 5 } & 1 & 2 & 3 & 4 \\
\hline P0 & $4.01 \mathrm{a}$ & $10.48 \mathrm{a}$ & $103.18 \mathrm{a}$ & $57.21 \mathrm{a}$ \\
P1IS & $4.16 \mathrm{~b}$ & $11.07 \mathrm{a}$ & $114.82 \mathrm{a}$ & $58.80 \mathrm{a}$ \\
P2IS & $4.21 \mathrm{~b}$ & $11.62 \mathrm{a}$ & $118.17 \mathrm{a}$ & $62.44 \mathrm{a}$ \\
P3IS & $4.12 \mathrm{~b}$ & $11.63 \mathrm{a}$ & $117.97 \mathrm{a}$ & $59.69 \mathrm{a}$ \\
P4IS & $4.16 \mathrm{~b}$ & $11.91 \mathrm{a}$ & $118.51 \mathrm{a}$ & $62.66 \mathrm{a}$ \\
P5IS & $4.20 \mathrm{~b}$ & $12.32 \mathrm{~b}$ & $121.38 \mathrm{~b}$ & $65.06 \mathrm{a}$ \\
P6IS & $4.30 \mathrm{~b}$ & $12.57 \mathrm{~b}$ & $127.78 \mathrm{~b}$ & $70.54 \mathrm{~b}$ \\
P7IS & $4.37 \mathrm{~b}$ & $12.73 \mathrm{~b}$ & $130.08 \mathrm{~b}$ & $75.83 \mathrm{~b}$ \\
P8IS & $4.43 \mathrm{~b}$ & $13.10 \mathrm{~b}$ & $137.41 \mathrm{~b}$ & $81.28 \mathrm{~b}$ \\
\hline BNT $_{0.05}$ & 0.13 & 1.54 & 17.82 & 9.58
\end{tabular}

Keterangan:Angka-angka pada kolom yang sama diikuti oleh huruf yang sama menunjukkan tidak berbeda nyata dengan P0 pada uji $\mathrm{BNT}_{0.05}$. 1. diameter tongkol $(\mathrm{cm})$, 2. panjang tongkol $(\mathrm{cm}), 3$. bobot tongkol kering panen per tanaman $(\mathrm{g})$ dan 4 . Bobot biji kering pipil per tanaman $(\mathrm{g})$.

Tabel 6 Nilai koefisien korelasi antar sifat dengan daya hasil (bobot biji kering pipil Per tanaman)

\begin{tabular}{llc}
\hline No & Sifat yang Diamati & Koefisien korelasi dengan daya hasil \\
\hline 1 & Tinggi tanaman & $0.70 \mathrm{~s}$ \\
2 & Jumlah daun & $0.43 \mathrm{~s}$ \\
3 & Jumlah daun segar & $0.49 \mathrm{~s}$ \\
4 & Bobot berangkasan segar & $0.63 \mathrm{~s}$ \\
5 & Diameter tongkol & $0.87 \mathrm{~s}$ \\
6 & Panjang tongkol & $0.70 \mathrm{~s}$ \\
7 & Bobot tongkol kering panen & $0.85 \mathrm{~s}$ \\
\hline
\end{tabular}

Rata-rata daya hasil lebih tinggi dibanding populasi awal sejak siklus ke enam; bahkan oleh Aini (2018), membuktikan daya hasil tersebut lebih tinggi sejak siklus ke lima. Peningkatan rerata terjadi karena setiap siklus seleksi terjadi peningkatan frekuensi gen dan frekuensi genotip daya hasil. Beberapa sifat meningkat secara nyata sejak siklus pertama dan ada juga yang meningkat sejak siklus ke dua. Hal ini dapat terjadi karena setiap sifat disusun oleh jumlah lokus yang berlainan, sehingga perubahan frekuensi gen dan fekuensi genotipenya berlainan. Lokus-lokus penyusun setiap sifat dalam kromosum dapat terjadi tautan dan keeratan tautan tersebut dapat dilihat dari korelasinya. Rata-rata daya hasil lebih tinggi pada P8IS terjadi karena tanaman lebih tinggi (Tabel 4), ukuran tongkol lebih besar dan lebih panjang serta bobot tongkol lebih tinggi (Tabel 5). Nilai koefisien korelasi sifat-sifat tersebut juga mendukung, yakni korelasinya positi nyata. Tanaman yang tinggi akan memiliki kemampuan menangkap cahaya matahari lebih banyak, sehingga fotosintat yang dihasilkan lebih banyak. Fotosintat yang banyak mampu diterima oleh sink tanaman sehingga akan menyebabkan komponen hasil dan hasil yang lebih tinggi. Hal sama diperoleh oleh Subaedah 
et al. (2016), bahwa daya hasil semakin tinggi akibat tongkol semakin panjang dan oleh Abdalla et al. (2010), daya hasil memiliki koefisien korelasi positif nyata dengan bobot tongkol kering panen. Al-Naggar et al. (2016), juga memperoleh bahwa komponen hasil memiliki korelasi kuat dengan daya hasil. Nilai koefisien korelasi daya hasil dengan panjang tongkol dan bobot tongkol kering panen berturut-turut 0.70 an 0.85 (Tabel 6).

\section{KESIMPULAN}

Ragam genetik total daya hasil, bobot tongkol kering panen, dan berangkasan segar populasi siklus ke delapan hasil seleksi massa menggunakan indeks seleksi lebih kecil dibanding populasi awal. Rata-rata daya hasil, bobot tongkol kering panen, dan berangkasan segar populasi hasil seleksi siklus ke delapan lebih tinggi dibanding populasi awal. Seleksi massa dengan indeks seleksi sebaiknya tidak dilanjutkan pada siklus berikutnya, namun perlu adanya upaya untuk meningkatkan keragaman genetik khususnya untuk sifat yang diseleksi dan sifat yang diperbaiki.

\section{DAFTAR PUSTAKA}

Abdalla, A., M. F. Mahmoud, A. M. El. Naim. 2010. Evaluation of Some Maize (Zea mays L.) Varieties in Different Enviromnents of The Nuba Mountain, Sudan. Australian Journal of Basic and Applied Sciences 4 (12): 6605-6610.

Aini, H. 2018. Uji Daya Hasil Tanaman Jagung Hasil Seleksi Indeks Di Lahan Kering. Skripsi. Fakultas Pertanian Unram. Mataram. $54 \mathrm{~h}$.

Al-Naggar, A.M.M, M. M. M. Atta, M. A. Ahmed and A. S. M. Younis. 2016. Direct vs Indirect Selection for Maize (Zea mays L.) Tolerance to High Plant Density Combined with Water Stress at Flowering. Journal of Applied Life Sciences International 7(4): 117

Andriani, Suwarni W.B., S.H. Sutjahjo. 2015. Pendugaan Keragaman Genetik dan Heritabilitas Jagung Hibrida Silang Puncak pada Perlakuan Cekaman kekeringan. Informatika Pertanian 24: 91-100.

Asghar, M.J. and S.S. Mehdi. 2010. Selection Indices for Yield and Quality Traits in Sweet Corn. Pak. J. Bot., 42(2): 775-789.

Metode Seleksi Indeks. 2012. http://pttitb.wordpress.com/category/06-seleksi-berdasarkankarakter-kriteria-seleksi/62-seleksi-langsung/. [14 November 2018].

Kutka, F. 2011. Open-Pollinated vs Hybrid Maize Cultivars. Sustainability 3 (9): 1531-1554.

Mejaya, M. J., Azrai, R. N. Iriany. 2010. Pembentukan Varietas Unggul Jagung Bersari Bebas. hal. 55-73. Dalam Jagung: Badan Penelitian dan Pengembangan Pertanian. Jakarta.

Peter S. G. \& K. R. Lamkey. 2000. Effective Population Size and Genetic Variability in the BS11 Maize Population. Crop Sci. (40):338-346.

Subaedah, St., A. Takdir, Netty, D. Hidrawati. 2016. Evaluation of Potential Production of Maize Genotypes of Early Maturity in Rainfed Lowland. International of Agricultural and Biosystems Engineering 10 (10): 638-641. 
Sudika I.W., Parwata A.I.G.M., Soemeinaboedhy Ny. 2018. Respon Seleksi Massa Secara Tidak Langsung Terhadap Daya Hasil Tanaman Jagung Selama Tujuh Siklus di Lahan kering. Jurnal Sains Teknologi \& Lingkungan. 2: 144-52

Syukur M., S. Sujiprihati, R. Yunianti. 2012. Teknik Pemuliaan Tanaman. Penebar Swadaya, Jakarta. 